\title{
Engineering Education in Sub-Saharan Africa: Quest for Quality
}

\author{
Goolam Mohamedbhai
}

\begin{abstract}
Africa has huge potential for growth and development and its youthful population and abundant natural resources are key aspects that need to be fully exploited. Engineering is one area that requires specific attention as it provides highly skilled personnel for industrial development. Through essentially desk-top research, this paper surveys the challenges that Sub-Saharan Africa faces in promoting engineering, such as lack of engineering capacity, shortage of engineering technicians, poor quality and relevance of educational provision, lack of human and financial resources, and poor linkages with industry. The paper then identifies several regional initiatives to address some of these challenges. Most of these are fairly recent and have yet to develop, and while several of them encourage harmonisation of approaches and collaboration among African institutions, hardly any place emphasis on university-industry linkages. Accreditation of engineering qualifications in Africa is key to improving the quality of the awards. Only a few African countries have established a really robust accreditation system for engineering qualifications. This paper suggests that these countries should take the lead in assisting the other countries, on a sub-regional basis, to improve their accreditation system, the ultimate goal being to establish a Pan-African engineering accreditation system.
\end{abstract}

Key Words: Sub-Saharan Africa, Higher Education, Engineering, Quality, Accreditation

L'Afrique a un immense potentiel de croissance et de développement; sa jeune population et ses abondantes ressources naturelles en sont des aspects clés qui doivent être pleinement exploités. L’ingénierie est

* Note: This paper is an abridged version of the following report commissioned by the World Bank: 'Improving the Quality of Engineering Education in Sub-Saharan Africa' by Goolam Mohamedbhai, February 2014. 
un domaine qui requiert une attention particulière puisqu'il permet de former du personnel hautement qualifié dans le but de développer l'industrie. Basé sur une recherche informatique, cet article analyse les défis rencontrés par l'Afrique sub-saharienne dans sa promotion de l'ingénierie - notamment le manque de capacité dans le domaine, la pénurie d'ingénieurs techniciens, l'enseignement inadapté et de médiocre qualité, le manque de ressources humaines et financières ainsi que le manque de liens avec l'industrie. Cet article identifie ensuite plusieurs initiatives régionales qui tentent de remédier à ces problèmes. La plupart sont récentes et ont encore besoin de se développer. Tandis que certaines de ces initiatives encouragent l'harmonisation des approches et la collaboration entre les institutions africaines, peu mettent l'accent sur les liens entre l'université et l'industrie. L'accréditation des diplômes d'ingénieur en Afrique est aussi essentielle pour améliorer la qualité de la formation. Seuls quelques pays africains ont réussi à mettre en place un système d'accréditation rigoureux pour les diplômes d'ingénieur. Cet article propose que ces pays jouent un rôle moteur à l'échelle sous-régionale et aident les autres pays à améliorer leur système d'accréditation - l'objectif ultime étant la mise en place d'un système d'accréditation panafricain pour les études d'ingénierie.

\section{Introduction}

Africa, in particular Sub-Saharan Africa (SSA), has been experiencing robust economic growth in recent years, attracting significant foreign investment. However, the foreign investment projects are handicapped by an acute shortage of domestic skilled labour, making it necessary to import foreign skills. For Africa to sustain its unprecedented economic growth and become competitive, the development of its human capital is paramount, especially in the areas of science, engineering and technology (The World Bank: News, 30 June 20I4).

There is, in particular, an urgent need of engineering capacity in Sub-Saharan Africa for several reasons. First, for its infrastructural development to accompany its growth trajectory. Such development includes the construction of roads, bridges, buildings, airports, harbours, etc. Second, for accelerating its industrial development, especially in manufacturing, so that it becomes a net exporter rather than importer of manufactured goods. Third, for meeting its everincreasing needs in terms of energy to overcome the acute power shortages it experiences regularly. Fourth, for empowering it to take control of the mining of its rich natural resources, especially minerals, oil and gas, and of the refining of such resources before export.
And finally, for achieving the Millennium Development Goals (MDGs) (Royal Academy of Engineering, 20I2).

The objectives of this paper are to assess, essentially through desktop research, the current state of engineering education and training in Africa, to survey existing regional initiatives to improve the quality of engineering education and to look at the important aspect of accreditation of engineering programmes of African universities.

\section{Education and Training in Engineering Industry}

Engineering, like medicine, is an important field and some engineering activities carry risks to society, resulting, for example, from poor design, construction, operation or maintenance. The profession therefore needs to be regulated. Engineers also often need to operate in countries other than their own, and their qualifications and competencies need to be recognised across borders (Dixon, 20I3).

There are, broadly speaking, three categories of personnel in the engineering industry. These are professional engineers, technicians and craftsmen (or skilled workers). The education and training requirements of the engineering workforce vary from country to country, although there is an increasing tendency for harmonising the regulation of the profession within a specific region, for example Europe, and through the establishment of a regional qualifications framework. In Sub-Saharan Africa, these requirements have to a large extent been inherited from the former colonising countries - generally UK, France and Portugal.

This paper deals mainly with engineering education and training in Anglophone African countries. The academic qualification for a professional engineer is usually a three- or four-year Bachelor's degree in Engineering obtained from a university. This degree must be accredited or recognised by the national engineering regulatory body. It should be mentioned that the recognition of the engineering degree is still mandatory in all countries even if the institution awarding the degree has been quality assured by the national quality assurance agency. The graduate engineer then needs some years - generally between two and three - of experience as a trainee engineer under the guidance of a professional engineer. Many degree courses include period(s) of training in industry but this may not necessarily be recognised as post-degree training. At the end of the training, the trainee needs to be registered nationally as a professional engineer in order to practice the profession. Most regulatory bodies require the submission of a portfolio before registration; some have an examination and interview.

The engineering technician needs to follow a two- to three-year 
course at a polytechnic or technical college and obtain an engineering diploma (either higher or ordinary, depending on the duration of the course). There is no formal registration of technicians. A craftsman usually obtains the appropriate trade certificate after one to two years of study at a vocational training institute, and often obtains the qualification while training on the job.

In most Francophone countries, engineering education is provided at both universities and the 'Grandes Ecoles' (elite professional schools).

\section{State of Engineering Education and Training in Africa}

Several reports have been published to diagnose the problems encountered in the provision of engineering education and training in African countries. This section briefly reports on the findings of some of the more recent studies.

\section{Report on Engineering Capacity Needs in Sub-Saharan Africa}

The Royal Academy of Engineering (20I2) has published a comprehensive report on identifying engineering capacity needs in Sub-Saharan Africa. The report is based on a literature review, an electronic survey of II3 professional engineers and 29 decision-makers from I8 African countries, and interviews with I5 engineering stakeholders with experience of leading projects in various SSA countries. The report covered mainly Anglophone African countries.

A key conclusion of the study is that there is a severe shortage of skilled and experienced engineers in SSA, and that 'this lack of capacity at every level of the profession is a substantive obstacle to achieving almost all the development goals, from the provision of basic sanitation to the reduction of rural poverty'. And yet, in most countries, the study found notable levels of unemployment among engineering graduates, mainly because engineers were graduating without the necessary skills and experience to be employable, but also partly due to the local presence of foreign engineering firms who prefer to import their own skilled labour, or the reluctance of the graduates to take up poorly paid positions in rural areas.

A number of causes for the low capacity are identified in the report. These include: a low level of public investment in engineering infrastructure projects over several decades; the lack of adequate legislation to uphold engineering standards through requirements for professional registration; the lack of regulatory laws to force foreign companies to effect knowledge transfer to local engineers; the deficiency in resources of the engineering institutions to support engineering activities; the poor quality of engineering education, based on outdated teaching methods and curricula, which are not relevant to local needs and too theoretical, as tertiary education institutions lack resources for adequate laboratory experiments; the acute shortage of opportunities for engineering students to gain pre-qualification experience through short placement in firms, and adequate training once they graduate; and poor salaries for professional engineers, resulting in brain drain of engineering talent to other sectors or other countries.

The report proposes several capacity building strategies targeted at governments, industry and higher education institutions, as follows:

Governments: adopt industrial policies so as to create jobs, promote enterprise development and improve skills training; establish and enforce a statutory requirement for the professional registration of engineers; invest in higher education institutions to improve engineering education; develop policies to mitigate brain drain of engineers.

Industry: support higher education institutions by providing industrial placements for academic staff and work placements for undergraduates; provide continuous professional development opportunities for engineering staff; foreign companies to ensure knowledge transfer to local engineers.

Higher Education Institutions: continuously review and update engineering curricula and involve industry in the process; build stronger links with industry.

\section{Case Studies of Engineering Education in Nigeria, Ghana}

and Zimbabwe

The findings of the above report are very similar to those of another study undertaken on behalf of the African Technology Policy Studies Network in 2005, to evaluate the capacity of engineering education in Nigeria, Ghana and Zimbabwe with a view to assessing the extent to which the programmes prepare engineering graduates for their role in industrial development (Afonja, et al., 2005). Data were collected from desk research, administration of questionnaires, and interviews with students, teachers, graduates, employers, university leaders and heads of parastatal bodies. The main findings from the report are as follows:

- Although there was a policy for introducing technical subjects at secondary school level, complemented by practical work, and engineering university curriculum made provision for practical work as well as industrial experience, none of the institutions had the necessary resources for implementing these.

- Due to lack of funds, most of the institutions had no modern laboratory equipment, and library facilities were below standard.

- The engineering curriculum in the three countries were deficient 
in management and entrepreneurship education, which did not prepare students for self-employment; also, employers complained that the graduates had inadequate exposure to practical engineering and management courses, and had poor communication skills.

- In all the three countries there was hardly any faculty-industry cooperation for curriculum development, research or consultancy. Placement of students for industrial work was also problematic with industry unwilling to provide the necessary supervision.

- Academic staff had very little exposure to engineering practice and, although well-qualified academically, had no industrial exposure.

- Women were grossly under-represented in engineering education, constituting less than Io\% of the student population.

\section{UNESCO Report on Engineering}

In 20IO, UNESCO published a landmark report on Engineering, with contributions from I2O experts from around the world (UNESCO, 20I0). UNESCO has published its well-known Science Reports since I998 and, although science in its broad sense includes technology and therefore engineering, UNESCO responded to the call from the engineering community for a specific study on engineering, especially on the role of engineering in international development. The report emphasises the importance of engineering in achieving the MDGs, mentioning that in SSA alone it has been estimated that a staggering 2.5 million new engineers and technicians would be needed to achieve the MDG of improved access to clean water and sanitation.

The report succinctly summarises the key issues to be addressed for promoting engineering for development, and these are:

- create public awareness of engineering, affirming its role as the driver of social and economic development and innovation;

- generate statistics and indicators on engineering at national level;

- transform engineering curricula and teaching methods to emphasise relevance and a problem-solving approach; and

- encourage innovation and apply engineering and technology to global issues and challenges.

All the above are highly relevant to SSA.

The report generally has a global approach but it has a section on each region. The one on Africa focuses on four selected African countries, namely Ivory Coast, Ghana, Nigeria and Uganda. The write-up on Ghana provides general information on the industrial development in the country, with nothing specific on engineering education. However, the reports from the other three countries do outline the challenges with regard to engineering education, and these are summarised below.
Ivory Coast

In 2005 there were three public and six private universities; four public and Io 8 private 'Grandes Ecoles'; and 28 post-secondary institutions providing professional and technical training.

The steps to be taken for improving engineering education, as proposed in the report, include: investment in engineering institutions to improve teaching resources and laboratories, as well as the training and conditions of service of the engineering educators; provision of professional experience to engineering students in public and private sectors, to encourage employment and innovation; creation of a better environment for women engineers; development of the research and development environment in engineering institutions; greater engagement with engineering organizations; and having regular national surveys to collect statistics on engineering.

Uganda

The challenges facing engineering training institutions in Uganda are:

- increase in enrolment in engineering without accompanying increase in resources and facilities;

- severe shortage of staff and difficulty in recruiting and retaining staff, because of poor salaries and conditions of service; recruitment of part-time staff has not been satisfactory;

- the requirement for all engineering academic staff to have a PhD, which is considered unsustainable;

- outdated delivery mode of lectures and poor laboratory work experience as a result of obsolete and non-functional equipment and too many students;

- outdated curricula not relevant to the changing industrial environment; and

- poor linkages and cooperation with industry.

\section{Nigeria}

Nigeria produces about 3,500 engineers from its universities and polytechnics every year. That is a relatively small number for a country with a population of I4O million, and yet there is significant unemployment among engineering graduates. There is a general decline of the engineering profession in Nigeria as a result of the following factors:

- poor salary after graduation, coupled with decreasing employment opportunities in industries, some of which have reached their employment capacity, and some which have closed down or been relocated to other countries;

- a general lack of culture of maintenance of infrastructure, which 
reduces employment opportunities for engineers;

- lack of involvement of Nigerian engineers in major engineering projects, for example in the major gas and oil industry; and

- poor quality of engineering education, especially because of lack of properly equipped laboratories, resulting from insufficient investment by government in tertiary education.

\section{Key Issues for Improving Engineering Education and Training} Engineering Capacity Needs

The studies reviewed show that at present there is a severe lack of engineering capacity in SSA and it has to rely heavily on imported expertise in engineering. The lack of capacity results from two main sources. First, the insufficient output from the training institutions to meet the countries' requirements; and second, the poor quality and lack of practical experience and skills of the graduates produced, which often make them unemployable. These are the two fronts on which SSA countries have to tackle the challenge of improving engineering education and training in SSA.

As part of the World Bank's initiative on Partnership in Applied Science, Engineering and Technology (PASET) for Africa (UWN, 20 July 20I3), consultations were held with selected SSA countries to determine their skills requirements. It was found that several of them have assessed their skills needs. Ethiopia, Mozambique, Rwanda, Senegal have all developed their human resources plan recently, where skills needs are identified. Some countries have also focussed their planning on a specific area. Mozambique, for example, prepared a national higher education strategic plan which identifies science and engineering as the most critical area for development in the forthcoming years. Ethiopia has also developed its higher education development plan.

The successful implementation of a human resources or skill-needs plan that attempts to match demand and supply of human resources, requires a compilation of national data on employment as well as output from training institutions in each area, including engineering. It is important that this be done continually to enable adjustment to changing labour market needs. Equally important is the need to set up institutional mechanisms to assess demand, both in terms of numbers and skills, so as to enable institutions to adjust their programmes to develop the required competencies. This requires concerted efforts of several Ministries (e.g. Education, Planning, Labour, Economic Development, Finance) as well as of the training institutions. Such mechanisms and data are rarely available in SSA countries, where usually long-term manpower planning is undertaken as a one-off exer- cise and the data often become obsolete by the time they are published.

The use of global indicators for human resources in different areas and in different regions, for example those compiled by the UNESCO Institute for Statistics, can also be useful for comparative purposes, but Engineering is often classified under Science and Technology, which makes it difficult to extract the specificity of Engineering. It is important for African countries to set up a national database of both the output from engineering institutions, and the personnel employed in the engineering field at different levels.

An issue worth considering is whether there is a need for a comprehensive study on the future skill-needs in SSA, in view of the important role that the region is expected to play in the global economy over the next couple of decades. Such a study was carried out in Europe in 2008 by the European Centre for the Development of Vocational Training (Cedefop, 2008), with the objective of forecasting labour market skillneeds in the medium term. A key finding from the study was that, in Europe, there is a continuing shift away from the primary sector (mainly agriculture) and the manufacturing industries towards services and the knowledge intensive economy. What are the implications of these trends on the labour market in Africa, which has close ties with Europe? Would there also be a shift away from agriculture and the manufacturing industries in Africa? What is the potential of employment in the extractive industries in Africa? In addition to finding answers to such questions, the study would help towards the harmonisation process among African countries that is currently under way.

Lack of Engineering Technicians

It is usually accepted that for the effective operation of the engineering industry, the ratio professional engineer:technicians should be of the order of $\mathrm{r}: 5$ or $\mathrm{i}: 6$, clearly indicating that there needs to be a far greater number of technicians than engineers.

As mentioned earlier, there is a dearth of data on the employment situation in engineering in African countries. South Africa is the one country in SSA where the engineering profession is well organised and regulated, and it also keeps good employment records. Figures from a book on skills shortages in South Africa (Du Toit \& Roodt, 2009) show that, in 2005, there were 242,018 engineers and 334,078 technicians covering a wide range of engineering disciplines, giving a ratio of I:I.4, a far cry from I:5. This could also imply that a number of qualified engineers are underemployed and are working as technicians. This trend should not be dissimilar in other African countries. There is even a risk that the ratio will worsen as the majority of countries 
are upgrading their polytechnics and technical colleges to university status for offering degrees, without providing a replacement. South Africa is a typical example. In 2004, all its Technikons, which were acknowledged regionally and internationally as exemplary institutions for technical training, were converted to Universities of Technology. The latter still run some diploma/certificate courses, but their primary activities are to run degree and postgraduate courses and to undertake research.

While SSA unquestionably needs an increased pool of excellent professional engineers, it equally needs an even greater number of practically-trained, versatile technicians not only to support the professional engineers, but equally to service and initiate small- and medium-scale industries, especially in rural areas, in order to create employment, improve the quality of life and make fuller use of local resources. A major constraint, however, is the status of technicians. They are regarded as inferior to engineers, which is one of the reasons for the tendency to upgrade polytechnics and technical colleges to university status.

\section{Quality of Engineering Education}

As mentioned earlier, the paradoxical situation in Africa is that although there is a shortage of engineers, engineering graduates remain unemployed or are under-employed. There are several reasons for this and one of them is the poor quality of engineering education.

There is, first of all, an urgent need to upgrade the infrastructure and laboratories of the existing institutions. Publicly funded African tertiary education institutions have for several decades suffered from lack of investment, and this has led to a deterioration of their infrastructure. Laboratory equipment are out of date or are non-functional, and have not been repaired; libraries do not have the appropriate books and journals; and availability of ICT and computers is still limited.

The curricula of engineering courses also need to be revised. Most of them have been copied from universities in Europe or the USA, have not been updated and are not necessarily relevant to African situations. Very few African universities involve industry and other stakeholders to assist in revising their engineering curricula.

The teaching methodology also needs to be improved. Because of large student numbers, the subjects are mostly taught by the magisterial mode with hardly any opportunity for the students to discuss and interact with the lecturer or among themselves. It would be advisable to adopt the Problem-Based Learning (PBL) approach in engineering education (Gallow, D. 20I4). Such an approach could result in notice- able improvement in the students' ability to solving problems and, in addition, help them to acquire certain 'soft' skills such as good communication, team spirit, creativity and adaptability. Indeed, many employers give greater importance to soft skills than qualifications. And PBL need not be laboratory-based or require expensive equipment and materials. Students could even be assigned problems to be solved while they are on training, matching the problems with the environment of their training.

Another important reason for the poor quality of teaching is the fact that engineering lecturers have not undergone any pedagogical training. Many of them have hardly had any industrial experience, although they may have a doctorate degree in their field. They are thus ill-equipped to help students to learn using appropriate pedagogical techniques. Pedagogical training of academic staff in universities in Africa is not widespread, although some institutions have made attempts to introduce it. Many universities are insisting that all their lecturers should have a PhD. This may not necessarily be the right approach for all engineering lecturers, and in any case may not be feasible. For many of them, having a good Master's degree in the appropriate field, acquiring some industrial experience and undergoing pedagogical training would better equip them for their teaching.

Linkages with Industry

All the studies on improving engineering education highlight the importance of strong university-industry linkages. A recent study undertaken by the Association of African Universities and the Association of Universities and Colleges of Canada (Ssebuwufu, Ludwick \& Beland, 20I2) found that while several higher education institutions in Africa are taking steps to link with industry, others have limited experience, expertise and resources to do so.

The need to involve industry in advising on curricula reform has already been mentioned. But this process needs to be formalised to make it effective. Representatives from industry should be invited to serve on the Faculty of Engineering board or even on the higher administrative bodies of the institution. Also, professionals from business and industry can be used as adjunct professors. Not only does this make up for the acute shortage of academic staff in most higher education institutions, but it also exposes students to the practical aspects of their studies and provides direct contact with industry.

Perhaps the most important role of industry is to provide practical training to the students at two different stages: during the course, in the form of industrial attachments, which exposes the students to the 
world of work and which subsequently facilitates their employment; and on completion of the course, to meet the necessary professional registration requirements. There are different thoughts on the most appropriate formula to be used. Some universities prefer short industrial attachments during the vacation period of the course, with the students obtaining more substantial training once they have graduated. Others prefer a sandwich formula with almost equal periods of training in industry alternated with teaching at the university. Whichever formula is used, such industrial training is vital for engineering students and graduates.

Several universities in Africa have abandoned the in-course industrial attachments because of the difficulty in placing the ever-increasing number of students, leaving the students to acquire training after graduation. This difficulty could well be an indicator of the poor absorption capacity for engineering graduates in the country. Another reason is that industry, especially private firms, find it difficult to supervise the students and assign them meaningful tasks, because of lack of staff and heavy work load. It is also true that the industrial environment in most SSA countries is not yet as developed as in other regions, and training and even employment opportunities are therefore limited. Nevertheless, this is an area where the Faculty of Engineering and the relevant stakeholders (industry, public sector and parastatal bodies employing engineers, engineering associations, etc.) need to meet to discuss the best approach to be adopted, taking into account the challenges and constraints on all sides.

Several countries, including China, Korea and Japan, have engineering projects in Africa and they should make a commitment to providing industrial training to local engineering students and, as far as possible, employing the engineering graduates from the local institutions. This would be the ideal approach to technology transfer and would help to empower the local engineering industry. One could also consider the possibility of mounting a programme whereby the engineering academic staff from African institutions spend a short period in the relevant industry in those countries to get industrial experience.

Some African universities and governments require graduates to work in rural areas for about a year on completion of their studies. This is an excellent way for young engineering graduates to be exposed to indigenous practices and skills and to contribute to sustainable development. Another way of linking the university with the rural community would be to have students posted in rural areas for practical training as part of their industrial attachment. This would not only expose students to problems of rural development, but would also help in bringing these problems to the university for possible solutions through projects (Mohamedbhai, I994).

\section{Regional Initiatives to Improve Engineering Education and Training}

There are several regional initiatives to improve engineering education and training in Africa, yet there is a dearth of information on such initiatives and the ones presented here are by no means exhaustive.

African Network for Scientific and Technological Institutions (ANSTI) The African Network for Scientific and Technological Institutions (ANSTI, 2OI3) is a regional non-governmental organization which was established in 1980 by UNESCO with funding from United Nations Development Programme (UNDP) and the German Government, to facilitate collaboration among African scientific institutions for the purpose of training and research in science, engineering and technology. ANSTI's Secretariat is housed in the UNESCO Nairobi office.

ANSTI has a membership of nearly 200 members (Faculties/ Schools of Science, Engineering and also Agriculture) in 37 countries (Anglophone, Francophone and Lusophone) of SSA. Of these, 85 are Engineering Faculties/Schools. An interesting event of ANSTI is the biennial Conference of Vice-Chancellors, Provosts, Deans of Science, Engineering and Technology (COVIDSET). The $5^{\text {th }}$ Conference was held in Botswana in 20I3. ANSTI also publishes the biannual African Journal of Science and Technology.

ANSTI also offers postgraduate fellowships for studies mainly in African universities, as well as grants for staff exchange purposes and for senior academic staff of its members to attend international conferences.

UNESCO Engineering Initiative (UEI)

Following the publication of the 2OIO UNESCO Report on Engineering, in November 20II the UNESCO Engineering Initiative (UEI, 20I3) was established to address major challenges in engineering as identified in the Report. These include the shortage of engineers, decreased interest in engineering as career option for young people, the underrepresentation of women in engineering, and brain drain from some countries. In line with UNESCO's global priorities, the UEI focuses on the African region and on women.

UEI has established fruitful partnerships with a number of organisations, including ANSTI, the American Society of Mechanical Engineers (ASME), the Institute of Electrical and Electronics Engineers, UK (IEEE) and the World Federation of Engineering Organisations 
(WFEO), to develop projects in these major themes: engineering education, women in engineering, and interdisciplinary and sustainable engineering. In 20I2, UNESCO and IEEE signed a Memorandum of Understanding (MoU) for improving engineering education and, in Africa, preliminary actions identified were accreditation, faculty development, curricula development and quality assurance in pilot African universities. It was also agreed to establish a UNESCO-IEEE Chair in Innovation at an African university. UNESCO has also signed a MoU with ASME to improve the quality of engineering education, increase public awareness of the value of the engineering profession, and promote science, technology, engineering and mathematics (STEM) training and careers.

The UEI is a relatively new initiative and the proposed activities in Africa have yet to evolve. The fact that it is initiated and led by UNESCO gives it a special international status.

\section{Tuning Africa Project}

The Tuning Africa project forms part of the Africa-European Union strategic partnership and aims to apply the well-established Tuning methodology, which is a collaborative, consultative process involving academics, employers and other stakeholders to improve curriculum and enhance student competencies. A pilot project on applying the Tuning process, which has been used in over 60 countries of the world, is being implemented in universities in the five regions of Africa in five selected subject areas (Hahn and Teferra, 20I3). In each region, a university was identified to lead an identified subject area, and that university then networks with a group of other universities in other African countries to apply the Tuning process to the respective subject area. The five identified subject areas include Civil Engineering (led by Ethiopia) and Mechanical Engineering (led by Cameroon). The Civil Engineering group has ten universities, including three Francophone ones; while the Mechanical Engineering group has twelve universities, including four Francophone ones.

The Tuning process is an onerous one and requires expert guidance. But its strength lies precisely in that process of consultation of all the stakeholders by the academics, which ensures quality and relevance of the programmes and greatly improves the employability of the graduates. The approach adopted in Africa of linking a group of universities in different countries to work together in a particular subject area, regardless of linguistic barrier, makes it particularly attractive. The approach could also have a multiplier effect in other subject areas in the same institution.
The pilot phase started in 20II and has been completed. The next phase of Tuning (2014-2020) started in 20I4 and the plan is to extend the methodology to additional universities, to undertake more in-depth work in the selected five disciplines by considering postgraduate level, and possibly to have additional disciplines included.

International Institute for Water and Environmental Engineering (2iE) The Institute, located in Burkina Faso, is commonly known as 2iE, the acronym derived from its French appellation. It was created in 2007 as a fusion of two existing engineering institutes which were set up in Ouagadougou, Burkina Faso, in I968 and I970, respectively, by the I4 countries of West and Central Africa. The new institution adopted a completely different and innovative approach in its governance structure, its international outlook, its academic programmes, its funding formula and the close links it established with industry.

The $2 \mathrm{iE}$ runs programmes from Bachelor's to Doctorate levels in water, environment, energy, civil engineering, mining and business administration, all directly relevant to Africa's needs (2iE, 20I3). It also places a strong emphasis on research. Its qualifications are accredited internationally, it attracts students from all over Africa and while it retains a Francophone bias, it is bilingual in its approach. It has a fulltime student population of some 2,000, and about I,500 professionals follow its various programmes by distance and online learning.

Its achievements so far have been impressive. According to its website, $90 \%$ of its students find employment within six months of graduation; $85 \%$ of its graduates work in the private sector; and $95 \%$ remain and work in Africa.

Although the $2 \mathrm{iE}$ is a single institution, it is a regional initiative in the sense that it receives government support from the countries in the West and Central regions of Africa, and it does serve the whole of Africa. It has recently been identified as one of the African Centres of Excellence to be funded by the World Bank. It is an example to be emulated in other parts of Africa.

African Engineering Education Association (AEEA)

Since 2002 a biennial African Regional Conference on Engineering Education (ARCEE) has been organised in Africa. A major outcome of the 3rd ARCEE in 2006 was the setting up of the African Engineering Education Association (AEEA, 2013). The objectives of the AEEA include organising ARCEE to promote networking among engineering educators; improving engineering teaching and learning in educational institutions; advocacy for government support for engineering 
education; involvement of African diaspora in the development of engineering education in Africa; and promoting exchange of students across the continent. The AEEA has six institutional members (four universities in Nigeria, one in Tanzania and one in Libya) and about 80 individual members from the whole African continent (not just SSA), plus a few from Europe and North America. About 30\% of the individual members are from Nigeria.

The 4th ARCEE was held in 2008 under the theme 'Capacity Building in Engineering Education for Sustainable Development'. The Conference took a number of resolutions, including the following: AEEA should urge African governments to generously invest in and support engineering education and training; AEEA should promote and facilitate international accreditation of engineering programmes of African institutions; engineering curricula and training should be dynamic, responsive to societal needs and incorporate links with industry; and AEEA should develop a database of engineering institutions in Africa, indicating the available capacity and areas of strengths in order to identify the capacity building needs of the institutions. At the same Conference, the Emerald/Africa Research Fund Award was launched to encourage research in engineering.

In November/December 2009, a 2I-member delegation from AEEA attended the China-AEEA 'Research and Study Seminar on Engineering Education and Project Management for African Countries', hosted by the Tsinghua University Centre for Engineering Education in Beijing. A major outcome of that seminar was the signing of a MoU for cooperation between Tsinghua University Centre for Engineering Education and AEEA. The scope of the cooperation includes joint research on China-Africa engineering education; organisation of fora on engineering education; publication of research papers; and exploration of potential collaboration between Chinese and African engineering education institutions.

The 5th ARCEE organised by the AEEA was held in Lagos, Nigeria in September 20I3 under the theme 'Harnessing Scarce Resources for Advancement of Engineering Education'. There was also a proposal to create an African Deans Council at that Conference, following the initiative to create the Global Engineering Deans Council in 2008 (GEDC, 2013).

AEEA appears to be a very interesting and dynamic organisation. The fact that it is led essentially by individuals rather than institutions could be a weakness, although this should be overcome by the creation of a Deans Council.
Africa Engineers Forum (AEF)

Established in I995, the AEF is a network of engineering organisations that 'subscribe to shared values in support of viable and appropriate engineering capacity in Africa' (AEF, 20I3). It currently has I6 national African Engineering Institutions as signatories, mostly from the Southern African Development Community (SADC) countries but also from Ghana and some East African countries. Its secretariat is housed at the South African Institution of Civil Engineering. AEF collaborates in the Africa-UK Engineering Partnership for Development (see below), but apart from that it does not appear to have any significant projects. It might well be subsumed under the Federation of African Engineering Organisations (see below).

Federation of African Engineering Organisations (FAEO)

The FAEO brings together Engineering organisations from all over Africa and is a member of the World Federation of Engineering Organisations (WFEO). It was created in May 2012 and its ambition is to build a united umbrella body for all African engineers. Its website provides no information about its objectives but according to its President, the FAEO aims 'at entrenching unity of purpose amongst all nations of the world to emancipate Africa from poverty through science and technology' (FAEO, 20I3). Its constitution recognizes five regional Federations of Engineering Organisations (Central, Eastern, Northern and West Africa) to operate under the FAEO. It has also created several Standing Technical Committees.

\section{Africa-UK Engineering for Development Partnership}

This Partnership, launched in 20IO, brings together the engineering community in Africa and the UK in a consortium led by the AEF, The Royal Academy of Engineering, Engineers Against Poverty and the Institution of Engineers (UK). Its purpose is to strengthen the capacity of the African engineering profession and promote mutually beneficial links between engineers in Africa and the UK (Africa-UK Engineering for Development Partnership, 2013).

In 2010 and 20II, the Partnership held a series of workshops in SSA. The one held in Zimbabwe in November 20II was under the theme 'Engineering Education', where delegates discussed opportunities to improve the engineering curricula in African universities and ensure that graduate engineers are equipped with the skills and knowledge needed to promote sustainable development and fight poverty.

In 2012 and 2013 the Partnership planned to run a programme on 'Enriching Engineering Education in Sub-Saharan Africa', designed to 
bring engineering curricula in universities in line with current industrial practice and to improve teaching practices in engineering. The Partnership also planned to launch an Africa Prize to recognise and reward innovation and entrepreneurship in engineering in SSA. It has not been possible to obtain information on developments on these activities.

There appears to have been a lull in the dynamism of this Partnership after its operation in the first two years.

\section{Overview of Initiatives}

The majority of the initiatives have been operational fairly recently and their activities have yet to develop fully. There is no initiative to encourage young engineering faculty to spend some time in industry to gain industrial experience. Also, although there are initiatives for curricula reform, for these to be effective they must be accompanied by pedagogical training of faculty; no such initiative could be found. Similarly, except at $2 \mathrm{iE}$, there is no regional initiative to facilitate the placement of engineering students for industrial training, especially in view of the difficulty encountered by most institutions in placing students for training in industry locally. In view of the importance and significant activities in, for example, the extractive industries, in construction and in Information and Communication Technologies in several African countries, such placement could greatly help students to gain meaningful experience and even subsequent employment upon graduation.

\section{Accreditation of Engineering Qualifications}

Accreditation is the formal recognition of an education or training programme through a quality assurance process, to ensure that it meets the criteria prescribed for the type of programme. Usually, a decision is taken after an independent accreditation visit to the institution running the programme, to look at the curriculum, staffing, physical facilities, funding and management of the programme.

Accreditation of Engineering Qualifications in Africa

In the majority of African countries (but not the Francophone ones), the regulation of the practice of engineering is done by a single statutory body. In Nigeria this body is known as the Council for the Regulation of Engineering in Nigeria (COREN, 2013); in Kenya, Tanzania and Uganda it is the Engineers Registration Board (ERB); and in South Africa it is the Engineering Council of South Africa (ECSA, 20I4), one of the best known engineering regulatory body in Africa. The core functions of these bodies are accreditation of engineering programmes, registration of professionals in specified categories and regulation of the practice of registered persons or firms. In Ghana, there is no accreditation body specifically for engineering. The National Accreditation Board is responsible for accrediting all tertiary education institutions and programmes in Ghana, and the registration of engineers is done by the Ghana Institution of Engineers after they have passed the Engineering Professional Examination. A few African countries have similar arrangements.

It is often believed that the accreditation of engineering programmes is more appropriate for private institutions which may not meet the minimum criteria. However, almost all the accreditation bodies now make no distinction between public and private universities. Indeed, there is an example in Kenya where, in 20II, the ERB refused the recognition of the engineering degrees of three of the country's leading public universities (UWN, 20II, July). Also, a survey of I29 universities running engineering programmes in Nigeria revealed that, in I999/2000, only 2I of them were fully accredited by COREN, 39 were denied accreditation, and the remaining 69 obtained interim accreditation (Ajimotokan, et al., 20IO).

International Accreditation of Engineering Qualifications

At the international level, there are three agreements that govern the accreditation and mutual recognition of engineering qualifications. These are the Washington Accord for professional engineering qualifications, usually of four years' duration; the Sydney Accord for qualifications in engineering technology, usually of three years' duration; and the Dublin Accord for technician qualification, usually of two years' duration (IEA, 20I3). There are at present I5 signatories to the Washington Accord, nine to the Sydney Accord and eight to the Dublin Accord. A signatory is the national body responsible for accrediting engineering programmes in a country. Programmes accredited by any signatory body are recognised by the other signatories. There are strict procedures to be followed, requiring a long process, before a country can become a signatory to these Accords.

The I5 signatories of the Accords are: Australia, Canada, Chinese Taipei, Hong Kong China, Ireland, Japan, Korea, Malaysia, New Zealand, Russia, Singapore, South Africa, Turkey, UK and USA. South Africa, through its ECSA, is the only African country that is a signatory to all three Accords. The Accords make it possible for a signatory to assist one or more developing countries in eventually gaining signatory status. The two countries assisted by ECSA are Botswana and Namibia. 
Another international accreditation body is the Accreditation Board for Engineering and Technology, Inc. (ABET, 20I4), based in the USA. It is a non-governmental organisation that accredits post-secondary education programmes in applied science, engineering and engineering technology. To date ABET has accredited over 3,200 programmes from more than 670 universities and colleges. The bulk of these programmes are in the USA but there are also accredited programmes in 23 other countries. Of these countries, the only one from Africa is in South Africa, and within South Africa, the only institution which has ABET-accredited programmes is University of Pretoria. However, the two accredited programmes are non-engineering ones: Bachelor of Commerce in Informatics and in Information Systems.

ABET accreditation of a programme carries a significant initial cost as it requires an institutional visit of a review team of three persons over at least three days. These costs include accreditation review fees (which can be of the order of US $\$ 32,000$ ), air travel for the team members (usually in Business Class) and all their local costs. There is also an annual maintenance fee for the accreditation.

The question that arises is whether other African countries and institutions should aim at becoming signatories of the Accords or at ABET accreditation. There is no doubt that these bestow prestige and international recognition on the engineering qualifications. However, the main purpose of international accreditation is to facilitate the mobility of engineering professionals among the different countries especially the industrialised ones. But is this a priority for Africa? Would this not lead to greater brain drain of professionals from Africa to industrialised countries? Initiatives that encourage regional mobility of professional engineers within Africa would certainly be more important and appropriate.

Towards Regional Accreditation of Engineering Qualifications in Africa In Africa, most of the accreditation bodies have national jurisdiction. But there are examples of regional cooperation in engineering regulation. Recently, the ERB's of Kenya, Tanzania and Uganda signed a Mutual Recognition Agreement whereby programmes accredited in one country would be recognised in the other two (ERB Tanzania, 20I4). In Francophone Africa, the African and Malagasy Council for Higher Education (CAMES), which groups some I8 Francophone African countries, has a programme for the recognition and equivalence of diplomas (PRED) awarded in all the countries. PRED's recognition of a diploma in one country is binding on all the others, although the majority of cases CAMES deals with are qualifications from private institutions. In most Francophone countries the recognition of qualifications from public institutions is the responsibility of the relevant Ministry.

Perhaps Africa should aim at establishing a regional body for the accreditation of engineering qualifications, building up from subregional initiatives. In East Africa there is already a Mutual Recognition Agreement among the ERBs of Kenya, Tanzania and Uganda. The engineering accreditation bodies of the other countries of the East African Community, Rwanda and Burundi, could be brought on board. In Southern Africa, the very well established ECSA of South Africa, which already works with the accreditation bodies of Botswana and Namibia, could take the lead and establish a Mutual Recognition Agreement by inviting the other counties in the sub-region to join in. A similar approach could be adopted in West Africa with COREN of Nigeria leading the initiative.

ECSA, COREN and the ERBs of East Africa are probably among the best engineering accreditation bodies in Anglophone Africa. Other African countries have established such a body but they may not have the expertise, experience and resources to effectively undertake their accreditation functions. The sub-regional collaboration initiatives mentioned above would help to build their capacity. These initiatives should be supported by the well-established respective Regional Economic Community in each of Africa's sub-regions.

\section{Conclusions}

Africa stands at a crossroads in its development trajectory. It is widely acknowledged that the continent has huge potential for growth and development, and that its youthful population and abundant natural resources are key aspects that need to be fully exploited. Education and training, especially in science, engineering and technology, are necessary tools for the continent to unlock its potential.

Engineering is probably an area requiring most attention as it provides highly skilled personnel for technological and industrial development. However it faces a number of challenges, including poor quality and relevance of educational provision, lack of human and financial resources, and poor linkages with industry. These challenges need to be addressed jointly and urgently by African governments, engineering education institutions and representatives of industry and the private sector.

It is encouraging to note that several recent regional initiatives are already under way to address some of these challenges, as identified in this paper, and these need to be supported, nurtured and extended. Two important considerations that run through the initiatives are harmoni- 
sation of approaches and collaboration among African institutions.

Accreditation of engineering qualifications in Africa is key to improving the quality of the awards. Most African countries have taken steps towards accreditation of their engineering qualifications but only a few have really established a robust accreditation system. This paper suggests that these countries should take the lead in assisting the other countries, on a sub-regional basis, to improve their accreditation system, the ultimate goal being to establish a Pan-African engineering accreditation system.

In parallel to improving the quality of engineering education and training, there is a need to create a dynamic industrial environment in African countries. Only then can engineers thrive and achieve their full potential. Several of the countries that have significant industrial and manufacturing investments or are involved in major infrastructural development in Africa can be enormously helpful by providing professional training to engineering students, and by employing local engineering graduates whenever possible; in short by empowering African engineers and effecting technology transfer, vital for Africa's economic and industrial development.

To some extent, this is a 'chicken-and-egg' situation, as industrial development can only take place when there is a pool of trained technical manpower, and the training of technical personnel is dependent of industry's absorptive capacity. A national assessment of both engineering capacity and needs in African countries can be of great help towards this end. A similar regional assessment at the macro-level in Africa could also be very helpful.

\section{References}

ABET (Accreditation Board of Engineering and Technology). (2014). Information retrieved on January 03, 20I4, from http://www.abet. org/home/.

AEEA (African Engineering Education Association). (20I3). Information retrieved on December I9, 2013, from http://www.aeeaonline. org/events.html.

AEF (Africa Engineers Forum). (20I3). Information retrieved on December I9, 2013, from http://www.africaengineersforum.org/ index.html.

Afonja, A., Sraku-Larkey, K. and Oni, S.A. (2005). Engineering Education for Industrial Development: Case Studies of Nigeria, Ghana and Zimbabwe. ATPS Working Paper No. 42, Nairobi, Kenya. Retrieved on December I3, 20I3, from http://www.atpsnet.org/ Files/working_paper_series_42.pdf
Africa-UK Engineering for Development Partnership. (2013). Information retrieved on December 20, 20I3, from http://www.raeng.org. uk/international/activities/pdf/engdev/UK_intro_to_the_Partnership.pdf

Ajimotokan, H.A. et al. (2010). Engineering Education and Sustainable Development in Nigeria. USEP Journal of Research Information in Civil Engineering, 7(I). Retrieved on December 22, 20I3, from http:// unilorin.edu.ng/publications/ajao/Engineering\%2oeducation.pdf

ANSTI. (20I3). Information retrieved on December I8, 20I3, from http://www.ansti.org

Cedefop. (2008). Future Skills Needs in Europe: Medium Term Forecast. Synthesis Report. Retrieved on December I7, 20I3, from http://www.cedefop.europa.eu/EN/Files/4078_en.pdf

COREN (Council for the Regulation of Engineering in Nigeria). (2013). Information retrieved on December 22, 20I3, from http://www. coren.gov.ng/

Dixon, M. (20I3). Skills, Professional Regulation and International Mobility in the Engineering Workforce. Migration Policy Institute, Washington, DC. Retrieved on 22 December 2013 from http://www. migrationpolicy.org/pubs/Engineering-credentialrecognition.pdf

$\mathrm{Du}$ Toit, R. \& Roodt, J. (2009). Chapter 5: Engineering professionals in Skills shortages in South Africa - Case Studies of Key Professions, Erasmus, J. \& Breier, M. (eds.). Retrieved on December I7, 2013, from http://www.hsrcpress.ac.za/product.php?productid=2257

ECSA (Engineering Council of South Africa). (2013). Information retrieved on December 22, 2013, from https://www.ecsa.co.za/ default.aspx

ERB (Engineers Registration Board), Tanzania. (20I4). Information retrieved on January 03, 20I4, from http://www.erb.go.tz/

FAEO (Federation of Engineering Organisations). (20I3). Information retrieved on 20 December, 2013 from http://www.africaengineersforum.org/index.html

Gallow, D. (20I4). What is Problem-Based Learning? University of California, Irvine, USA. Retrieved on September 24, 20I4, from http:// www.pbl.uci.edu/whatispbl.html

GEDC (Global Engineering Deans Council). (20I3). Information retrieved on December I9, 2013, from http://www. gedcouncil.org/events/5th-african-regional-conference-engineering-education-lagos-nigeria-september-9-12-20I3

Hahn, K. and Teferra, D. (20I3). Tuning as Instrument of Systematic Higher Education Reform and Quality: the African Experience. Tuning Journal for Higher Education, November (I):I27-I63. 
IEA (International Engineering Agreements). (20I3). Information retrieved on December 22, 20I3, from http://www.washingtonaccord.org/

2iE (International Institute for Water and Environmental Engineering). (2013). Former et Innover pour Construire le Monde de Demain. Retrieved on December I8, 20I3, from http://www.2ie-edu.org/ assets/plaquette_institutionnelle_2iE_fr.pdf

Mohamedbhai, G.T.G. (I994). The emerging role of African universities in the development of science and technology'. Association of African Universities, Accra, Ghana.

Royal Academy of Engineering. (20I2). Engineers for Africa: Identifying Engineering Capacity Needs in Sub-Saharan Africa. Summary Report. Retrieved on December I3, 20I3, from https://www.raeng.org.uk/international/activities/pdf/RAEng_ Africa_Summary_Report.pdf

Ssebuwufu, J., Ludwick, T. and Beland, M. (20I2). Strengthening University-Industry Linkages in Africa: A Study on Institutional Capacities and Gaps. AAU, Accra, Ghana. Retrieved on December I8, 20I3, from http://www.aucc.ca/wp-content/uploads/20II/07/ aau-case-study-university-industry-linkages-africa.pdf

The World Bank: News. (20I4, 30 June). Partnering to Build Engineering, Scientific and Technical Skills for Africa's Socioeconomic Transformation. Retrieved on September I5, 20I4, from http: //www.worldbank.org/en/news/feature/2014/06/30/partnering -to-build-engineering-scientific-and-technical-skills-for-africassocioeconomic-transformation

UEI (UNESCO Engineering Initiative). (2013). Retrieved on December I8, 20I3, from http://www.unesco.org/new/en/natural-sciences/ science-technology/engineering/unesco-engineering-initiative/

UNESCO. (20I0). Engineering: Issues, Challenges and Opportunities for Development. Retrieved on December I6, 2013, from http:// unesdoc.unesco.org/images/oor8/001897/189753e.pdf

UWN (University World News). (20II, July). Kenya: Professional Bodies Reject Degrees. University World News, I79.

UWN (University World News). (20I3, 20 July). PASET - A World Bank Initiative for Skills Development. University World News, 28I. 